Bentham open
CrossMark
Content list available at: www.benthamopen.com/PHARMSCI/
DOI: $10.2174 / 1874-844901603010601$

\title{
Development and Validation of a Robust QSAR Model For Piperazine and Keto Piperazine Derivatives as Renin Inhibitors
}

\author{
Jimish R. Patel ${ }^{*}$ and Laxman M. Prajapati \\ Department of Pharmaceutical Chemistry, Shri B M Shah College of Pharmaceutical Education and Research, College \\ Campus, Modasa-383315, Gujarat, India
}

\begin{abstract}
:
Background:

The renin is a key performer in the renin-angiotensin system, and it offers a resource for the beneficial action of hypertension and heart malfunction. The keto piperazine based renin inhibitors have shown greater potential and good biavaibility.

\section{Objective:}

To develop a highly efficient QSAR model for 80 piperazines and keto piperazines to predict renin enzyme inhibitory activity.

\section{Methods:}

The renin inhibitory activity $\left(\mathrm{IC}_{50}\right)$ was considered as biological activity. Dragon software, version 5.5 was used for calculation of physicochemical parameters. Sequential MLR (multiple linear regression) is carried out to create quantitative structure-activity relationship models, which were again evaluated in support of statistical significance and analytical capacity by inner and exterior validation.
\end{abstract}

\section{Results:}

The greatest QSAR model was a correlation coefficient $\left(\mathrm{R}^{2}\right)$ of 0.846 , cross-validation correlation coefficient $\left(\mathrm{Q}^{2}\right)$ of 0.818 and, $\mathrm{R}^{2}$ pred of 0.821 . The leave one out cross validation method was used to assess the performance of the chosen model.

\section{Conclusion:}

The quantitative structure-activity relationship model suggests that the constitutional descriptors $(\mathrm{Sv}, \mathrm{nDB}, \mathrm{nO})$ play a vital role in binding of ligands with renin enzyme. The information presented provides important structural insight in designing more potent renin enzyme inhibitors.

Keywords: Competitive balance, novel descriptors, piperazine and keto piperazine derivatives, renin, renin binding, robust QSAR.

\section{INTRODUCTION}

The renin-angiotensin-aldosterone system (RAAS) is a key controller of blood pressure; it has a reno-protective function and a very significant position in the vascular reaction to the damage [1]. Renin is aspartic protease, which consists of one of the four key classes of peptide cleave enzymes [2]. It is concealed by the nephron in feedback to reduce circulation level and blood pressure. Renin cleaves the substrate angiotensinogen to provide the stationary angiotensin-I. Angiotensin converting enzymes convert Angiotensin-I to the pro-hypertensive agent angiotensin receptor blockers. The renin is an input performer in the renin-angiotensin structure, and its operation offers a resource used for the beneficial action of hypertension and heart malfunction.

\footnotetext{
* Address correspondence to this author at the Department of Pharmaceutical Chemistry, Shri B M Shah College of Pharmaceutical Education and Research, College Campus, Modasa-383315, Gujarat, India; Tel: +91-02772-231343; Fax: +91-02774-249482; E-mail: jimish_patel_1986@yahoo.co.in
} 
Renin hang-up is an eye-catching object for drug involvement due to its notable specificity intended for its substrate $[3,4]$. The key man-made molecules were peptide or peptide-like renin inhibitors remikiren and zanikiren showing poor oral bioavailability, quick elimination, little efficiency, and high rate of chemical synthesis. Just utilizing the combination of drug design and crystallographic structure analysis led to the development of aliskiren, non-peptide orally effective inhibitor of human renin [5 - 9].

Pfizer pursued the task of designing the keto piperazine based renin inhibitors which have shown greater potential $[10,11]$. More recently, a novel series of renin inhibitors based on the 3, 9-diazabicyclo nonene have been developed [12]. The piperazine and keto piperazine derivatives have been found to be potent, efficacious, oral and good bioavailable renin inhibitors $[11,13,14]$. In this study, novel quantitative structure-activity relationship models were built to illustrate the magnitude of the physicochemical properties intended for the piperazine and keto piperazine derivatives as renin inhibitors.

\section{MATERIALS AND METHODS}

A total of 80 piperazine and keto piperazine based renin inhibitors were included in Quantitative structure-activity relationship study as accounted in Table $\mathbf{1}$ [13]. $\mathrm{IC}_{50}(\mu \mathrm{M})$ values changed in logarithmic $(\mathrm{M})$ values, which were used for the regression studies.

Table 1. Molecules 's Structures and Experimental values of piperazine and keto piperazine based renin enzyme inhibitors.<smiles>[R][Z]([H])c1c([R])c([R])c([R])c(N2C(O[3H])C([R])NC([R])C2([R])[R])c1[R4]</smiles>

1 - 80

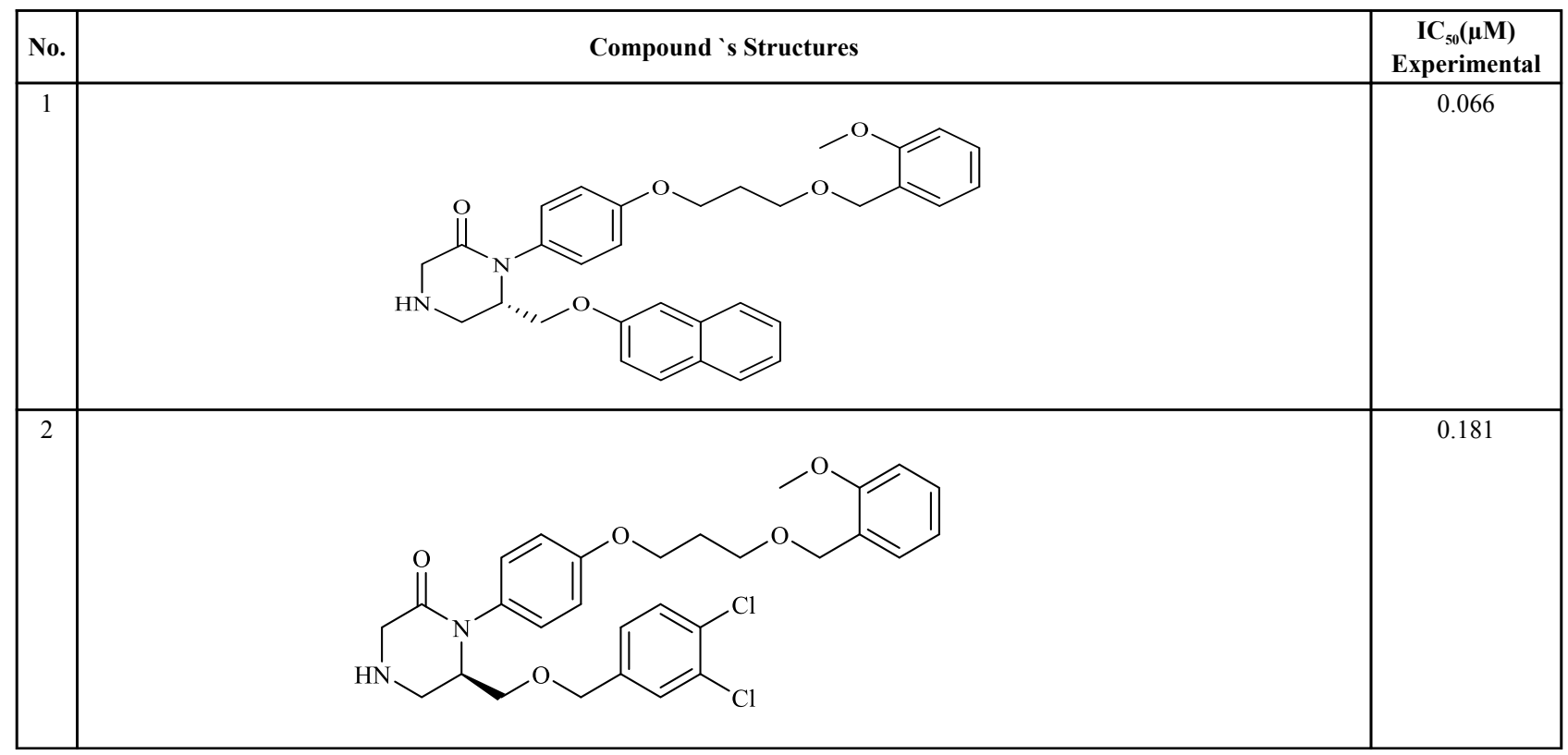


(Table $\square$ ] contd......

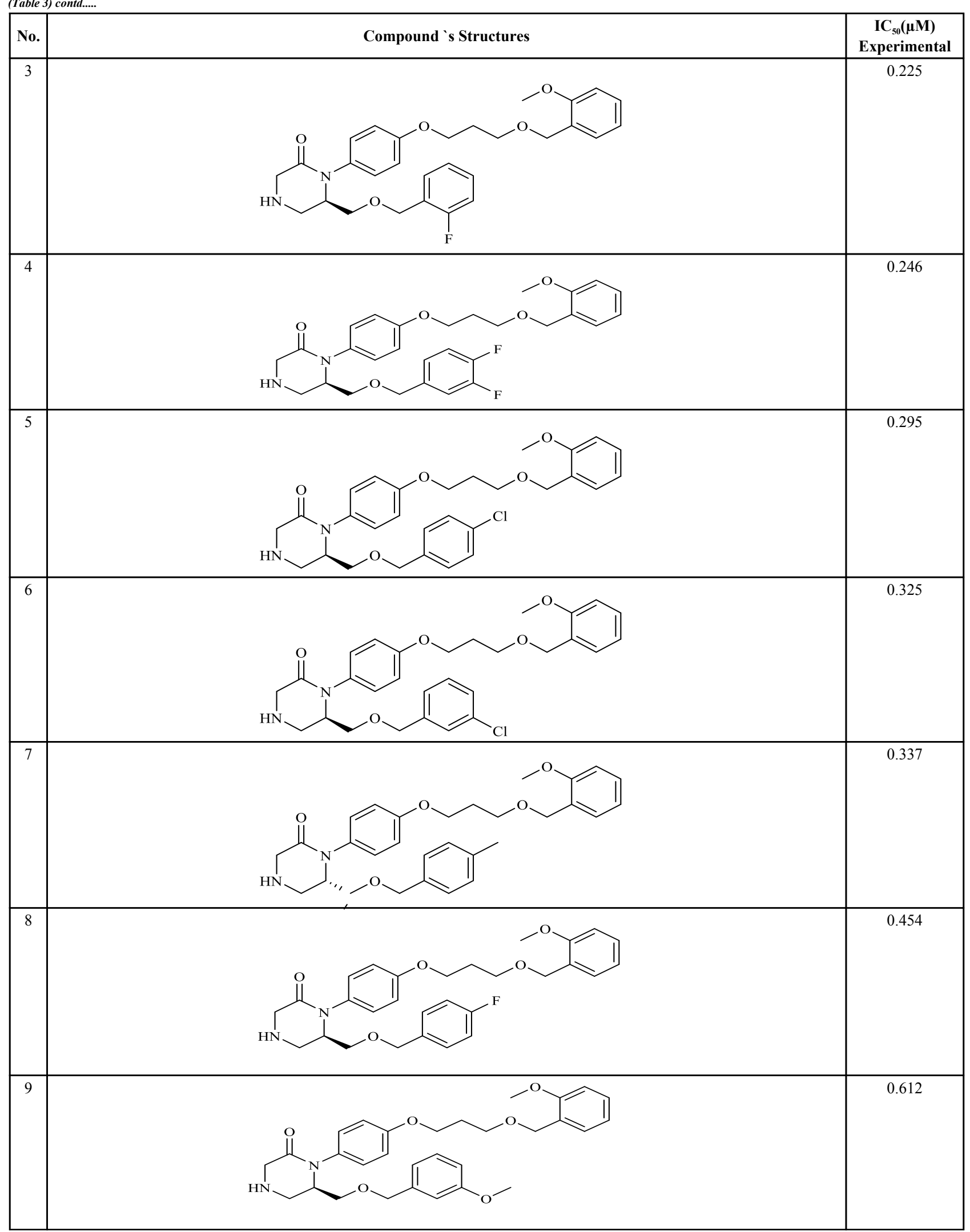


(Table $\square$ ) contd.....

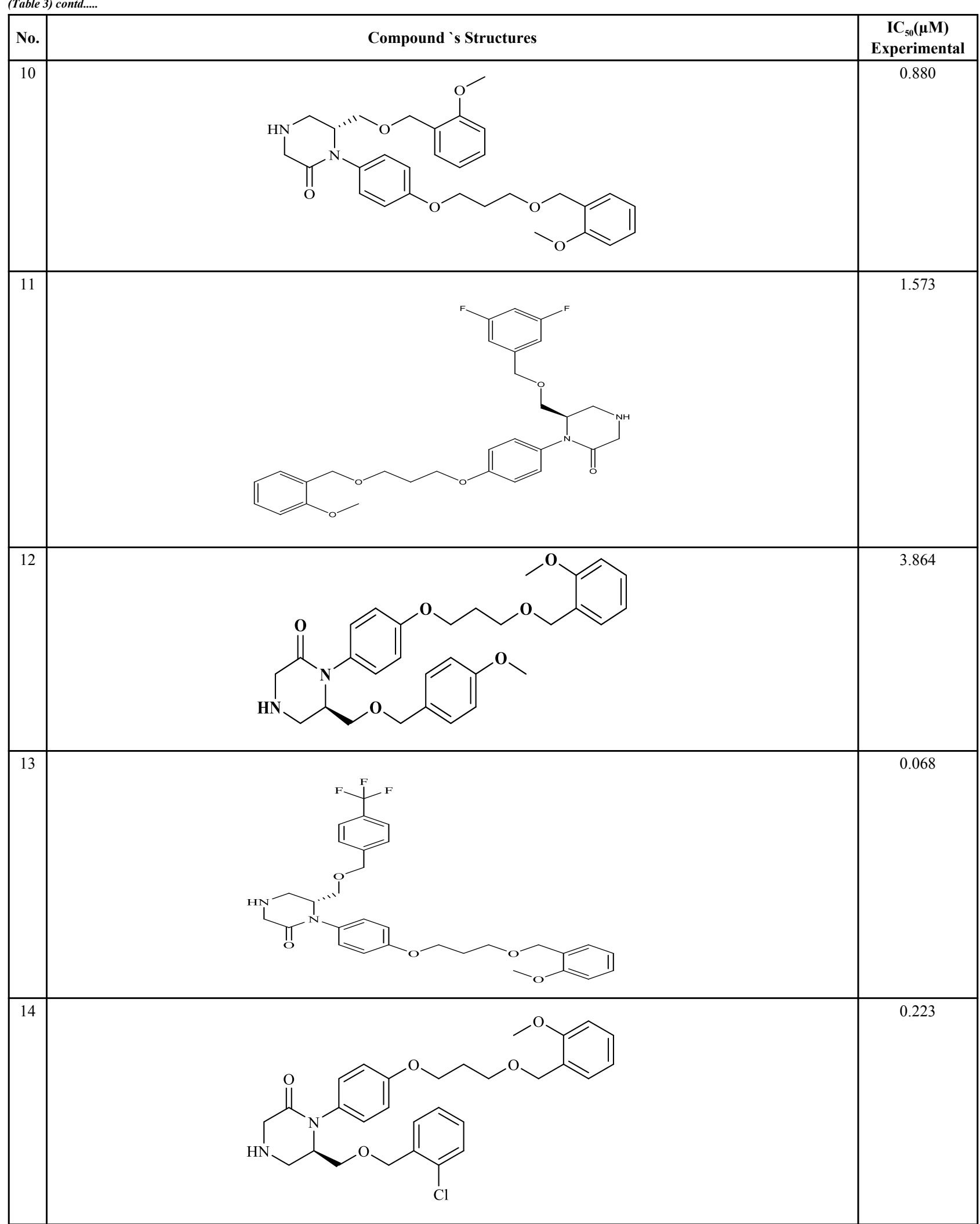


(Table $\square$ ) contd.....

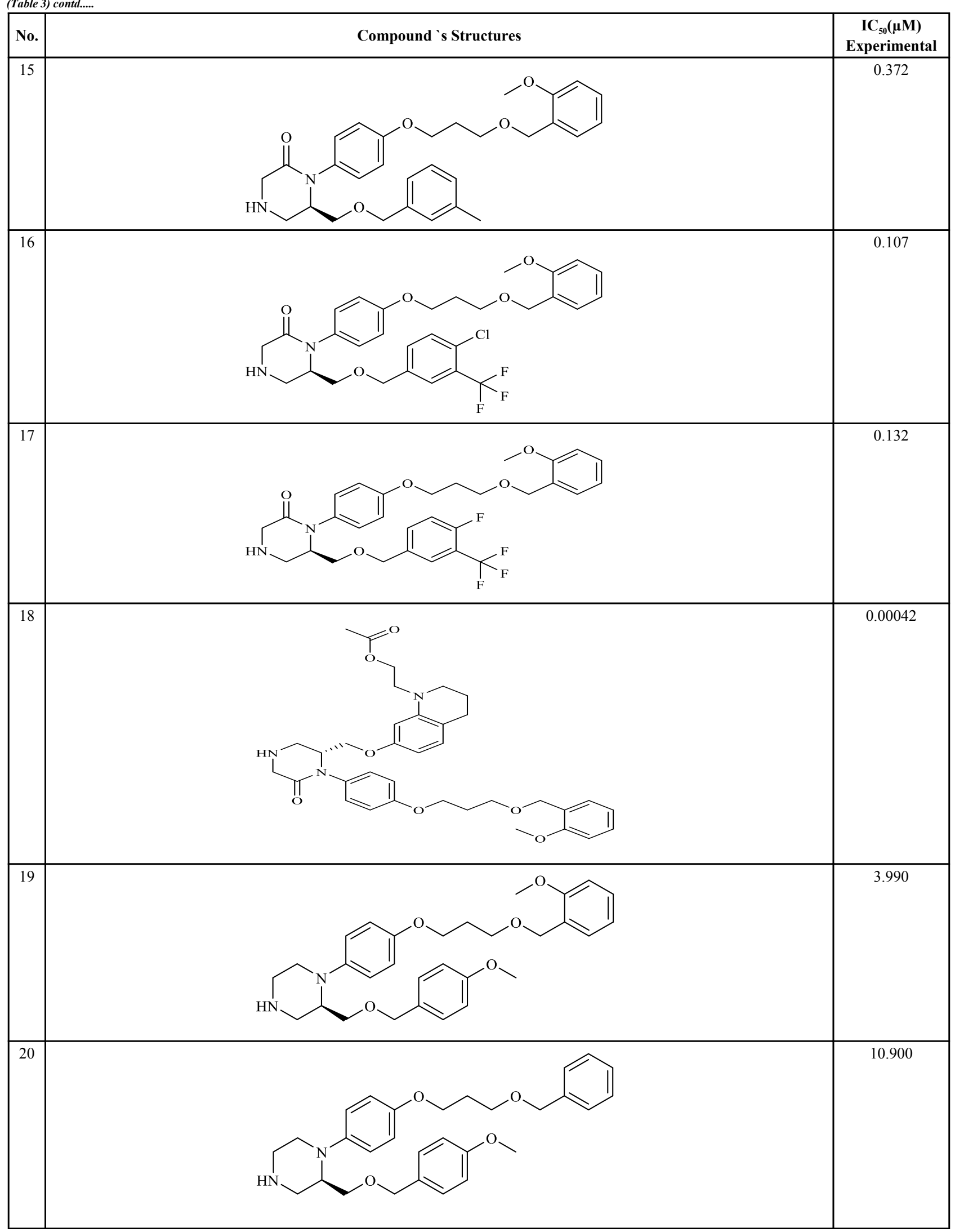


(Table $\square$ ) contd......

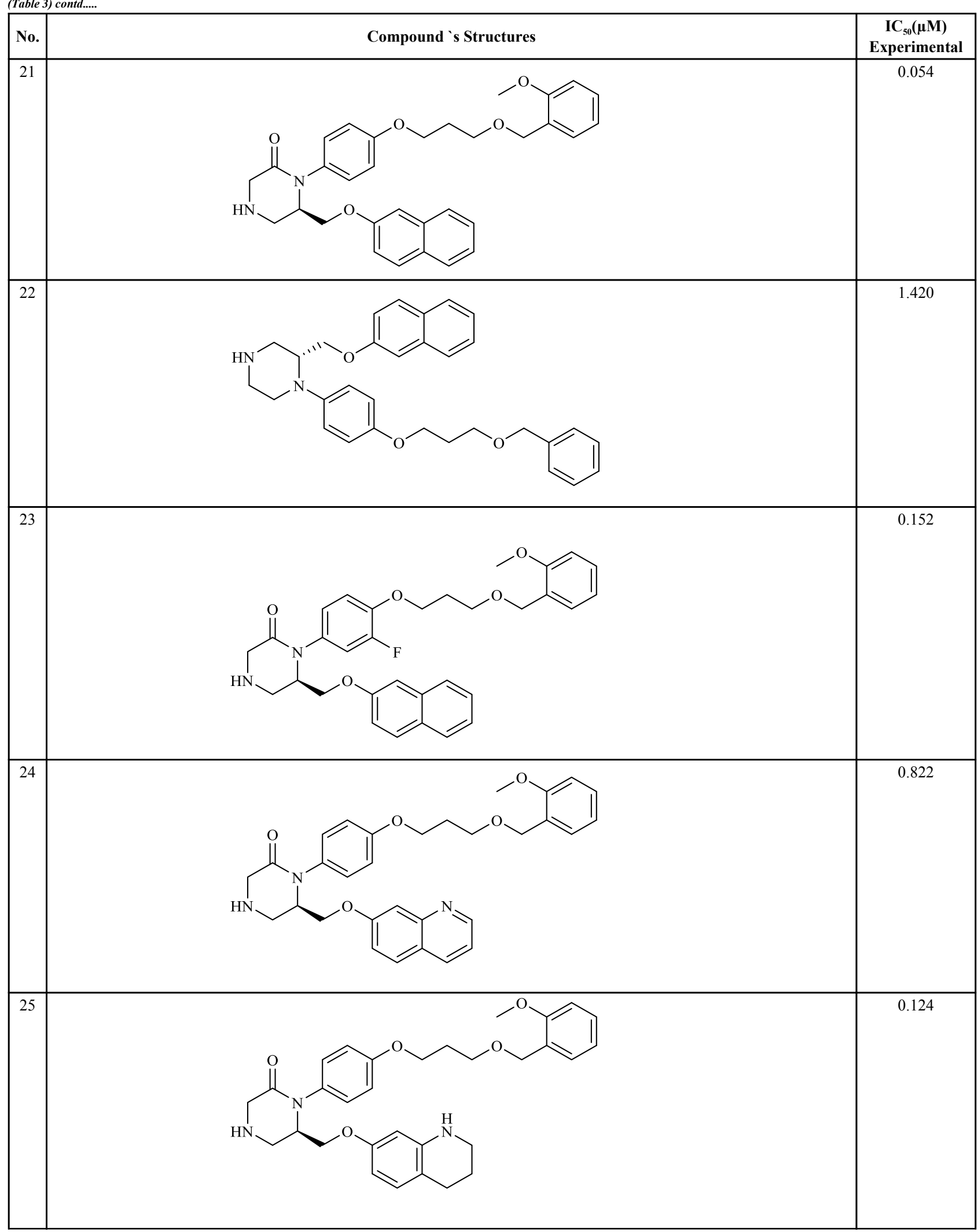


(Table $\square$ 凹) contd.....

\begin{tabular}{|c|c|c|}
\hline No. & Compound `s Structures & $\begin{array}{c}\mathrm{IC}_{50}(\mu \mathrm{M}) \\
\text { Experimental }\end{array}$ \\
\hline 26 & & 0.883 \\
\hline 27 & & 0.037 \\
\hline 28 & & 7.014 \\
\hline 29 & & 5.586 \\
\hline 30 & & 3.841 \\
\hline 31 & & 0.528 \\
\hline
\end{tabular}


(Table $\square$ ) contd.....

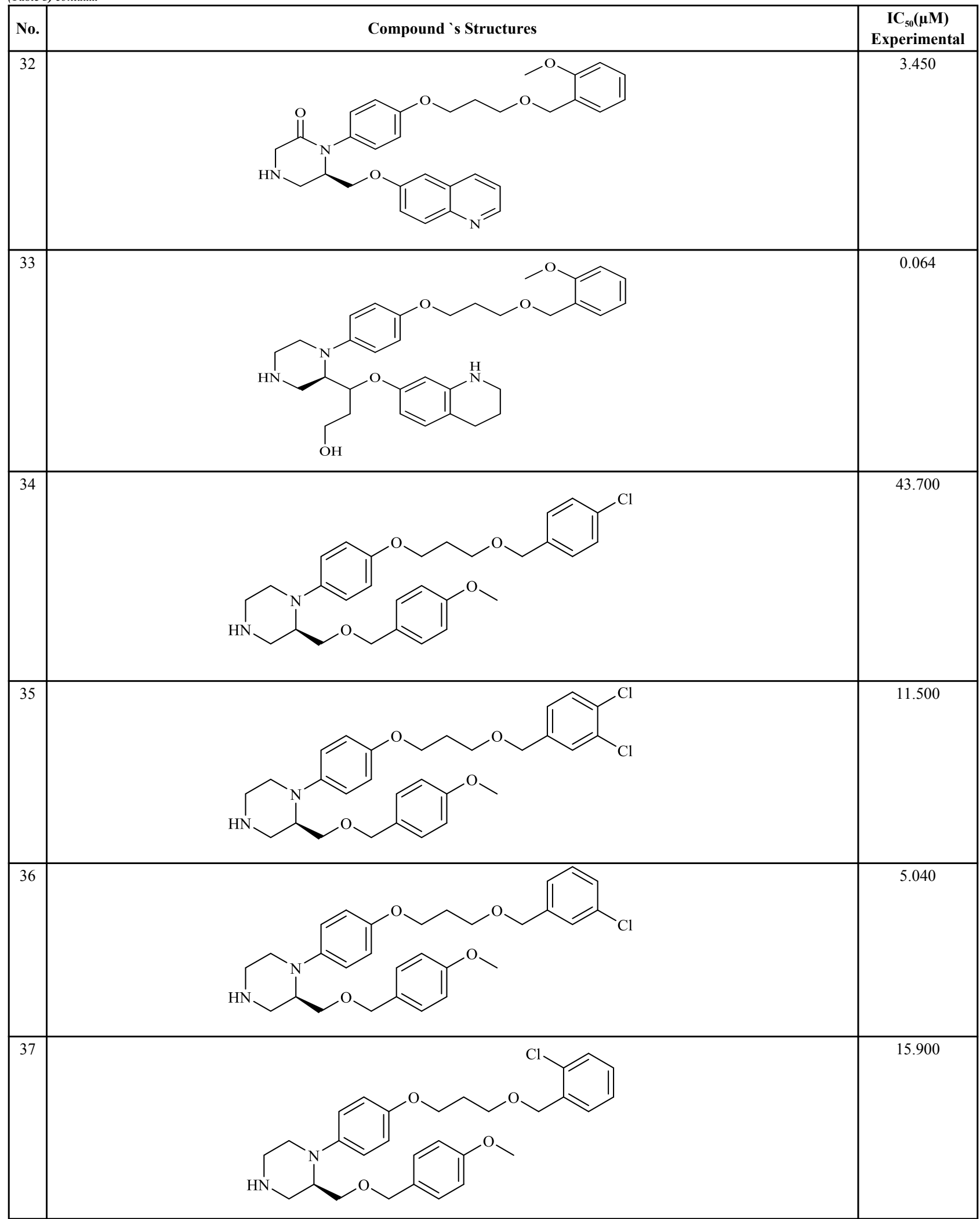


(Table $\square$ ) contd.....

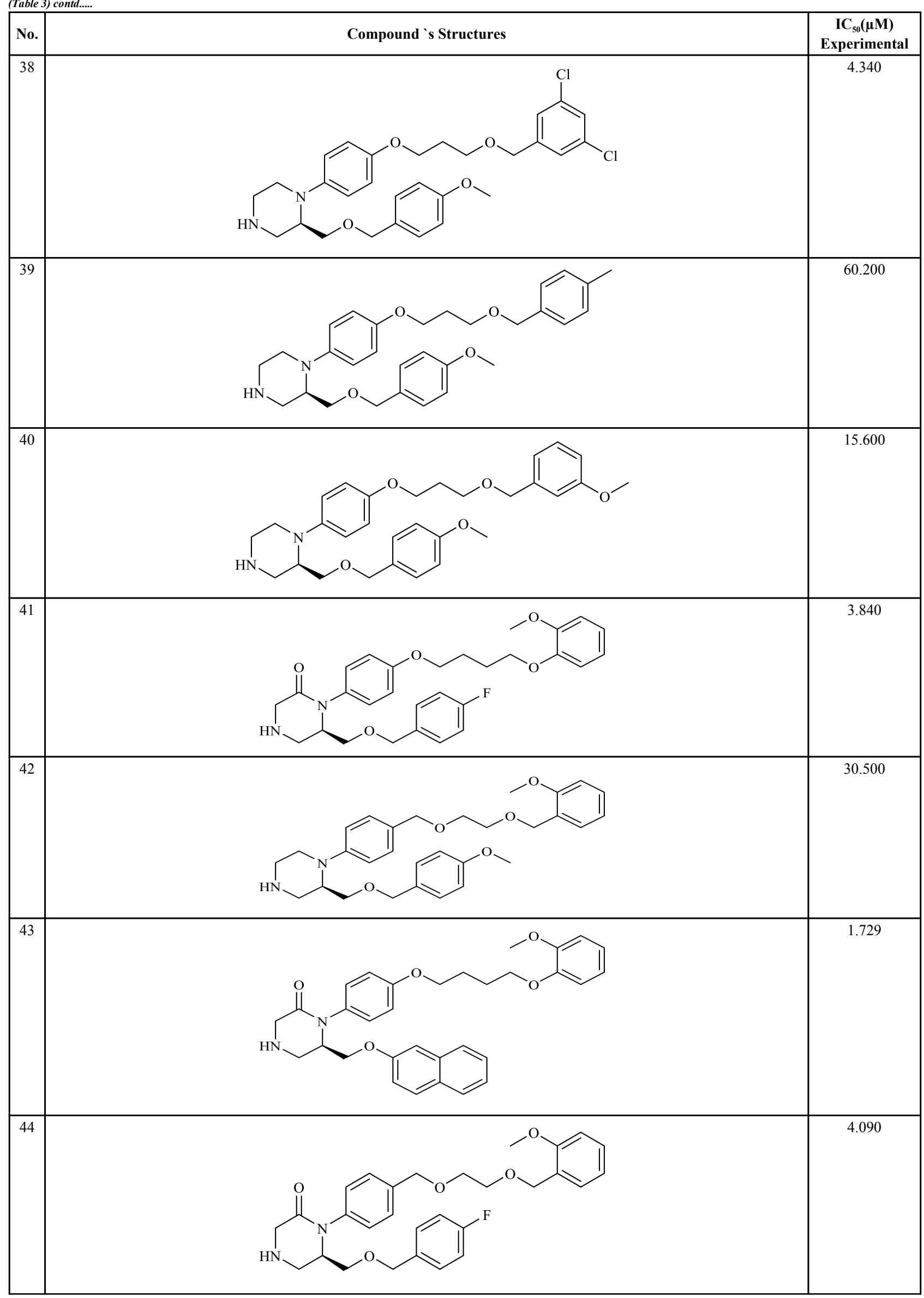




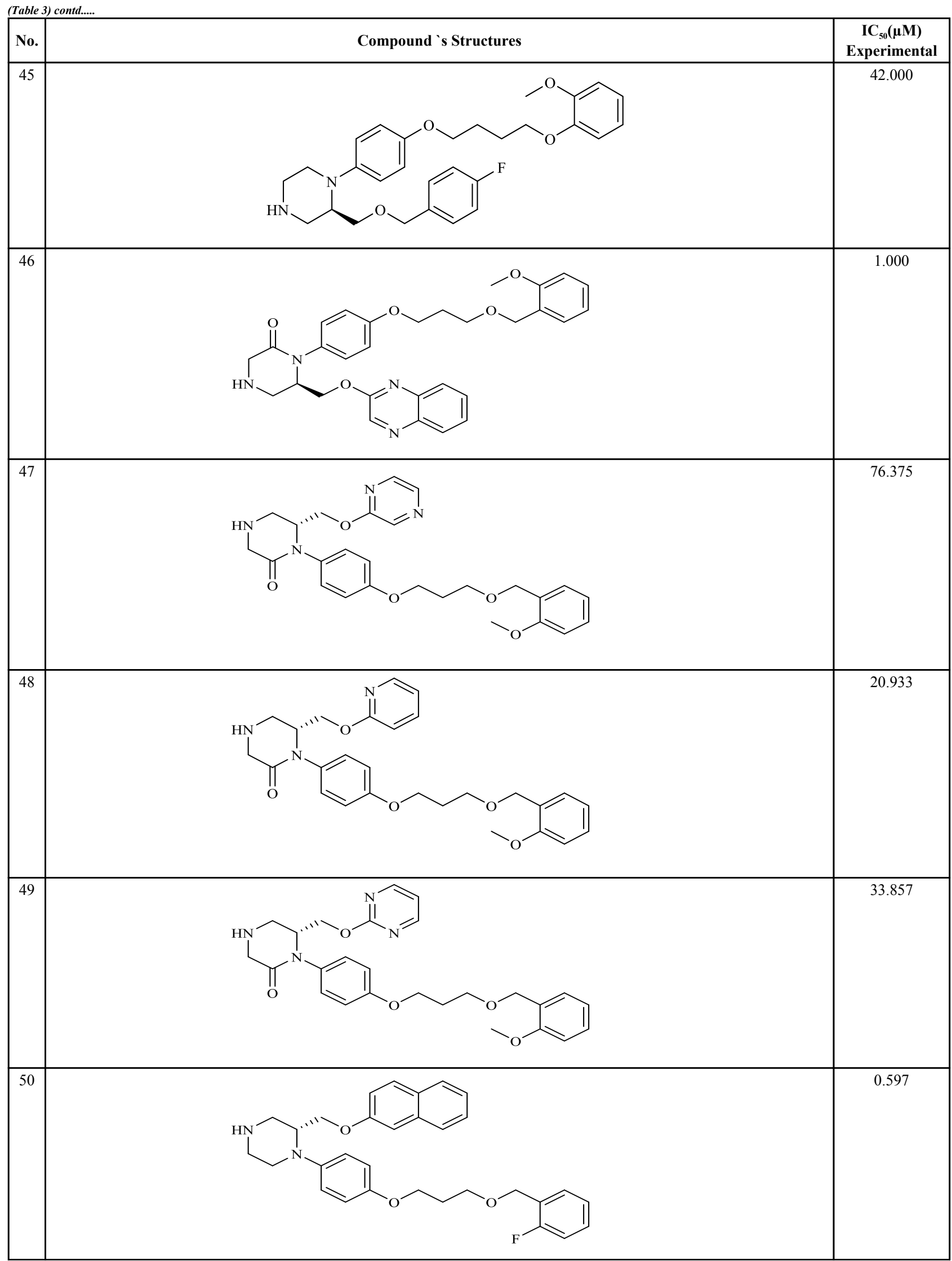




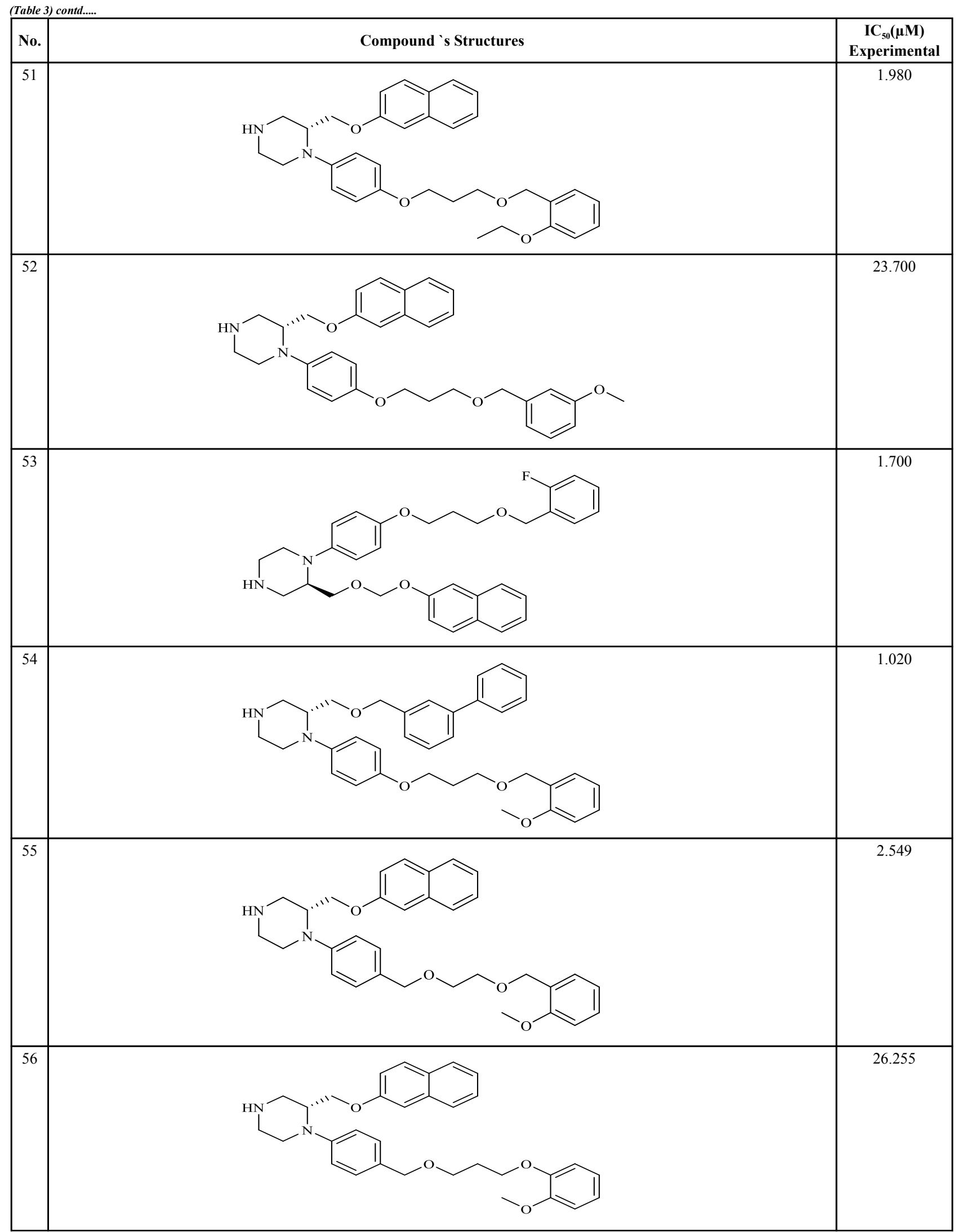


(Table $\square$ ) contd.....

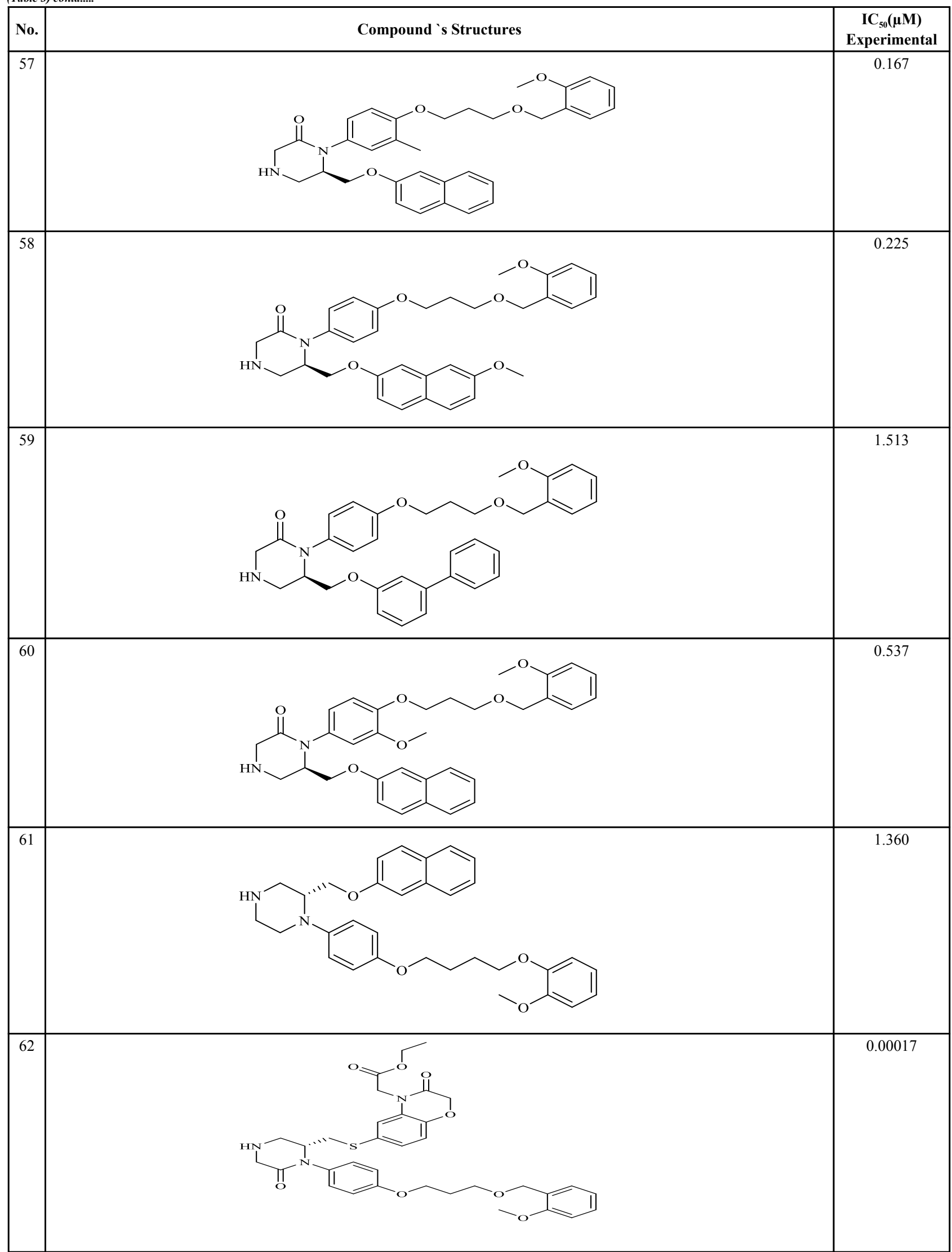




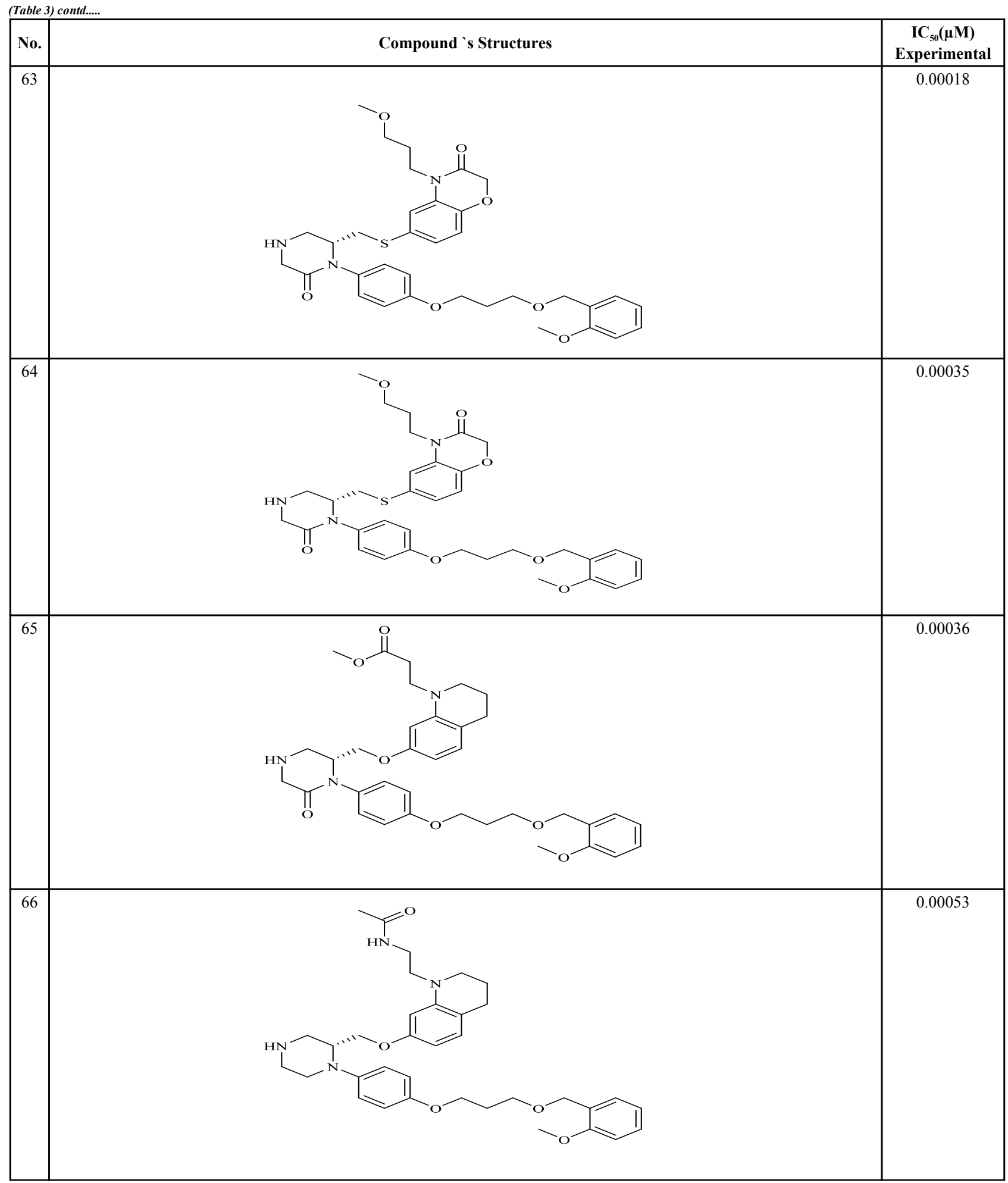


(Table 口) contd.....

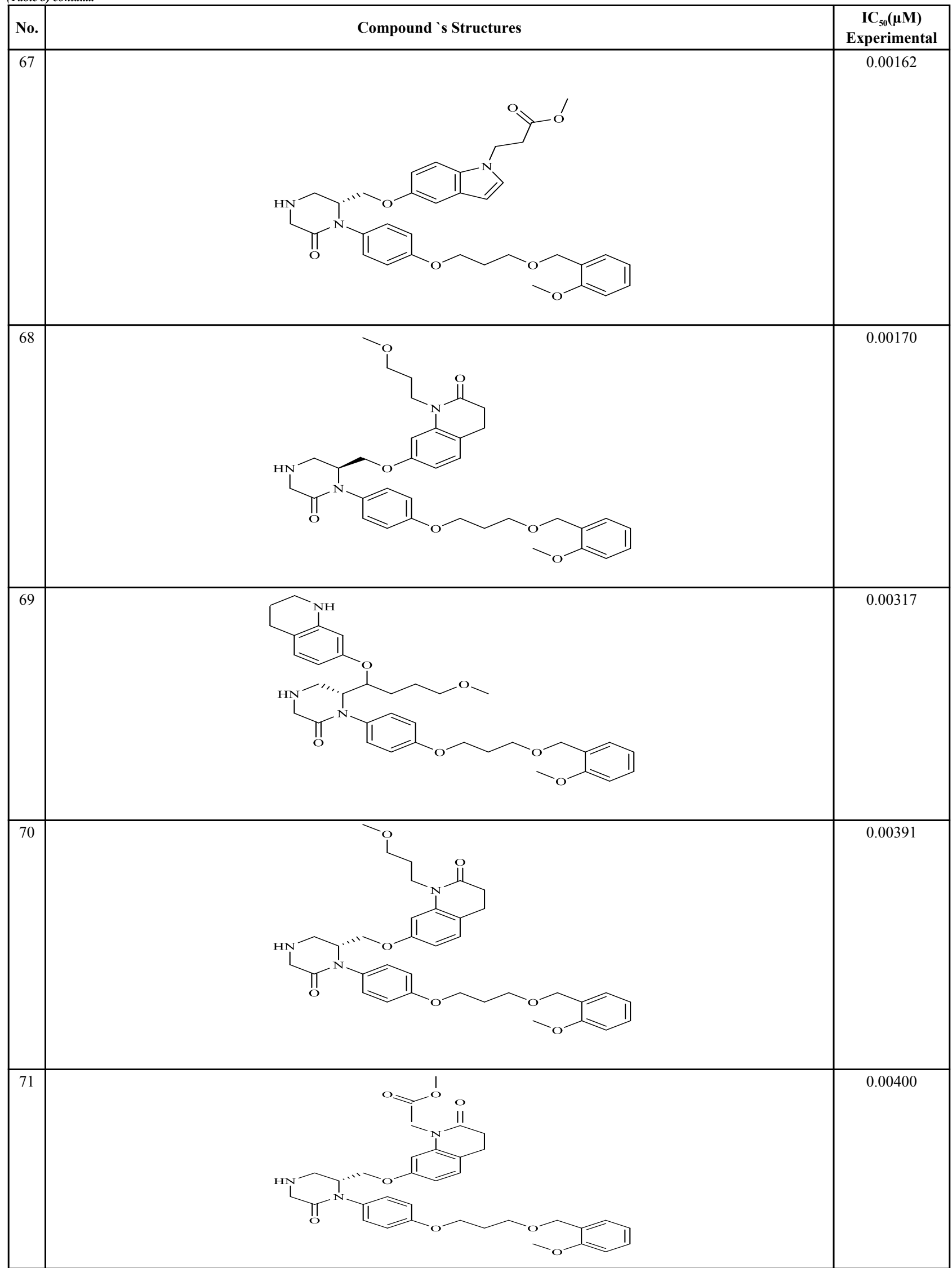


(Table $\square$ ) contd......

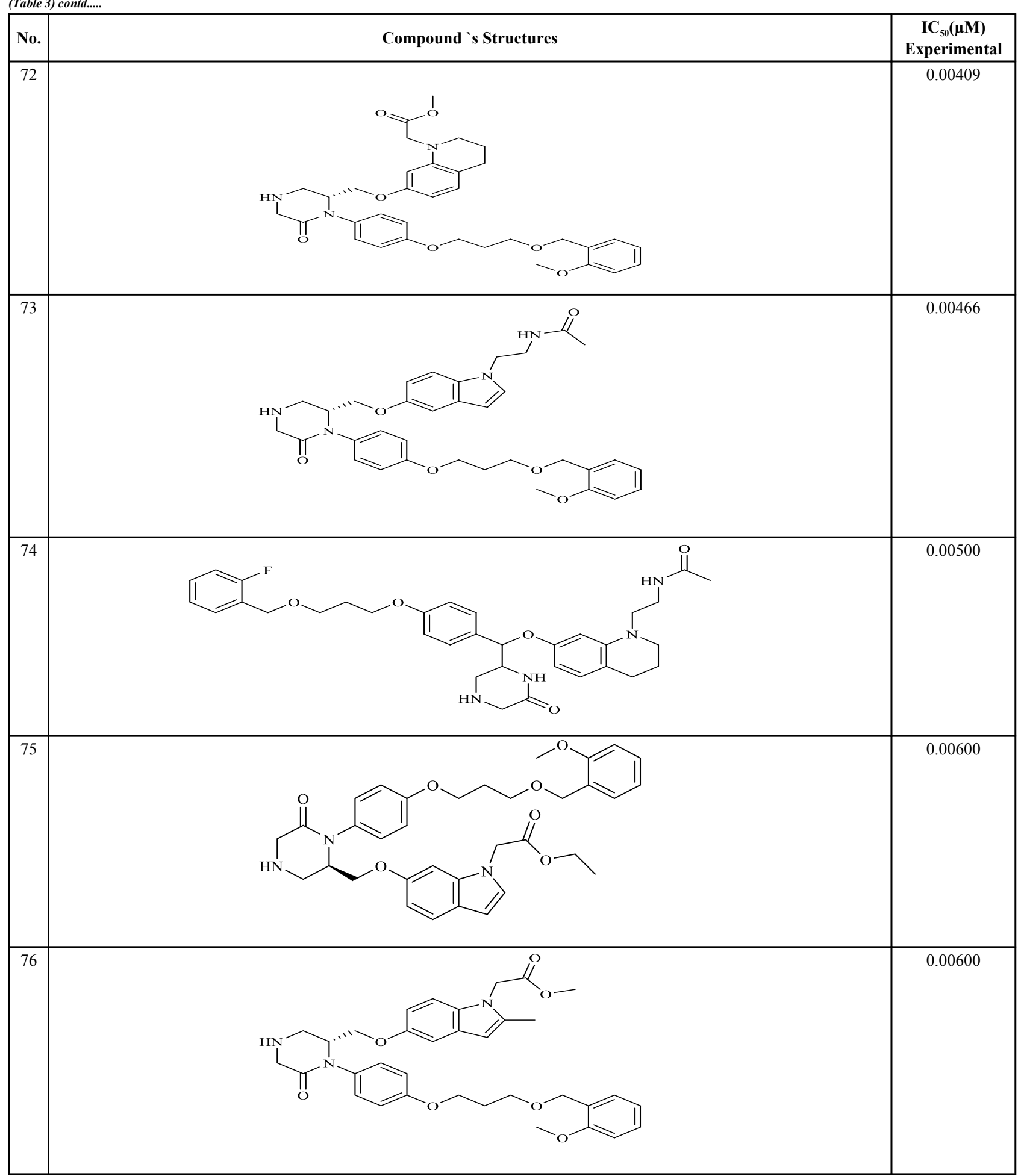




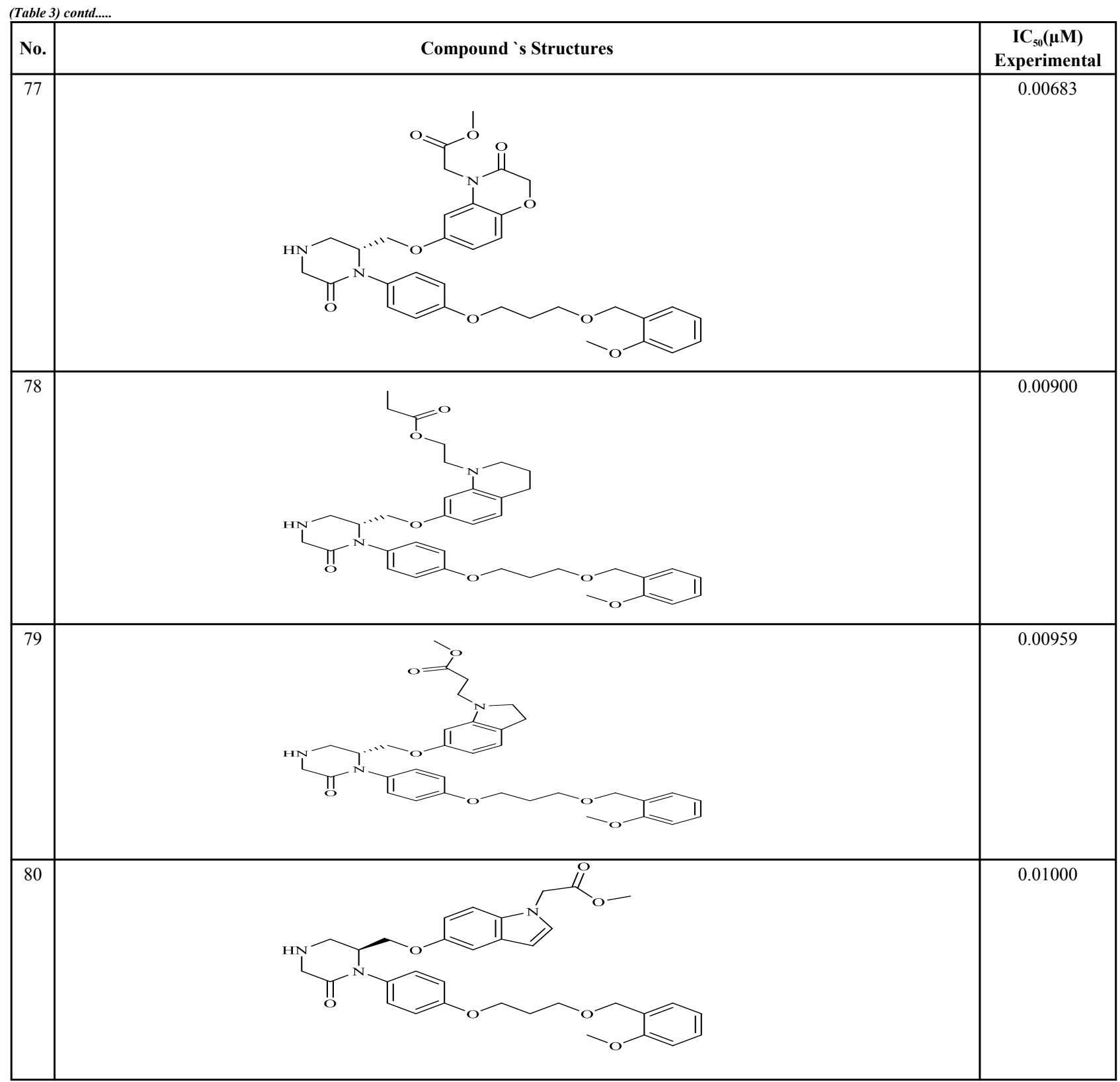

Molecules were randomly divided into the test set (24 molecules) and training set (56 molecules). The 2D structures were converted into 3D structures by using software Chem Office 2004, Version 8.0 [15]. The energy minimization was executed in two steps, in the first step energy minimized using molecular mechanics-2 (MM2) until the root mean square (RMS) gradient value attained the value smaller than $0.100 \mathrm{kcal} / \mathrm{mol} \AA$ and then in second step minimized molecules were subjected to re-optimization by MOPAC (Molecular Orbital Package) module using the AM1 procedure foreclosed shell system until the RMS gradient reached a value smaller than $0.0001 \mathrm{kcal} / \mathrm{mol} \AA$. Total 3224 molecular descriptors were calculated on the DRAGON Software, Version 5.5 (Table 2) [16].

Table 2. calculate values of various descriptors intended for the compounds

\begin{tabular}{|c|c|c|c|}
\hline NO. & ${ }^{\mathrm{a}} \mathbf{S v}$ & ${ }^{\mathrm{b}} \mathrm{nDB}$ & ${ }^{\mathrm{c}} \mathrm{nO}$ \\
\hline 1 & 46.11 & 1 & 5 \\
\hline 2 & 44.51 & 1 & 5 \\
\hline 3 & 43.22 & 1 & 5 \\
\hline 4 & 43.33 & 1 & 5 \\
\hline 5 & 43.81 & 1 & 5 \\
\hline 6 & 43.81 & 1 & 5 \\
\hline
\end{tabular}


(Table $\square$ ) contd........

\begin{tabular}{|c|c|c|c|}
\hline NO. & ${ }^{\mathrm{a}} \mathrm{Sv}$ & ${ }^{\mathrm{b}} \mathrm{nDB}$ & 'nO \\
\hline 7 & 44.71 & 1 & 5 \\
\hline 8 & 43.22 & 1 & 5 \\
\hline 9 & 45.22 & 1 & 6 \\
\hline 10 & 45.22 & 1 & 6 \\
\hline 11 & 43.33 & 1 & 5 \\
\hline 12 & 45.22 & 1 & 6 \\
\hline 13 & 45.04 & 1 & 5 \\
\hline 14 & 43.81 & 1 & 5 \\
\hline 15 & 44.71 & 1 & 5 \\
\hline 16 & 45.74 & 1 & 5 \\
\hline 17 & 45.15 & 1 & 5 \\
\hline 18 & 53.52 & 2 & 7 \\
\hline 19 & 45.31 & 0 & 5 \\
\hline 20 & 43.2 & 0 & 4 \\
\hline 21 & 46.11 & 1 & 5 \\
\hline 22 & 44.09 & 0 & 3 \\
\hline 23 & 46.22 & 1 & 5 \\
\hline 24 & 45.51 & 1 & 5 \\
\hline 25 & 46.7 & 1 & 5 \\
\hline 26 & 46.33 & 1 & 5 \\
\hline 27 & 52.01 & 1 & 6 \\
\hline 28 & 43.11 & 1 & 5 \\
\hline 29 & 43.22 & 1 & 5 \\
\hline 30 & 38.92 & 1 & 5 \\
\hline 31 & 45.51 & 1 & 5 \\
\hline 32 & 45.51 & 1 & 5 \\
\hline 33 & 50.5 & 0 & 5 \\
\hline 34 & 43.9 & 0 & 4 \\
\hline 35 & 44.6 & 0 & 4 \\
\hline 36 & 43.9 & 0 & 4 \\
\hline 37 & 43.9 & 0 & 4 \\
\hline 38 & 44.6 & 0 & 4 \\
\hline 39 & 44.8 & 0 & 4 \\
\hline 40 & 45.31 & 0 & 5 \\
\hline 41 & 43.22 & 1 & 5 \\
\hline 42 & 45.31 & 0 & 5 \\
\hline 43 & 46.11 & 1 & 5 \\
\hline 44 & 43.22 & 1 & 5 \\
\hline 45 & 43.31 & 0 & 4 \\
\hline 46 & 44.9 & 1 & 5 \\
\hline 47 & 40.31 & 1 & 5 \\
\hline 48 & 40.91 & 1 & 5 \\
\hline 49 & 40.31 & 1 & 5 \\
\hline 50 & 44.2 & 0 & 3 \\
\hline 51 & 47.8 & 0 & 4 \\
\hline 52 & 46.2 & 0 & 4 \\
\hline 53 & 46.31 & 0 & 4 \\
\hline 54 & 50.39 & 0 & 4 \\
\hline 55 & 46.2 & 0 & 4 \\
\hline 56 & 46.2 & 0 & 4 \\
\hline 57 & 47.71 & 1 & 5 \\
\hline 58 & 48.22 & 1 & 6 \\
\hline 59 & 48.71 & 1 & 5 \\
\hline 60 & 48.22 & 1 & 6 \\
\hline
\end{tabular}


(Table प) contd...

\begin{tabular}{|c|c|c|c|}
\hline NO. & ${ }^{\mathrm{a}} \mathrm{Sv}$ & ${ }^{b} \mathrm{nDB}$ & ${ }^{\mathrm{c}} \mathrm{nO}$ \\
\hline 61 & 46.2 & 0 & 4 \\
\hline 62 & 52.92 & 3 & 8 \\
\hline 63 & 53.01 & 2 & 7 \\
\hline 64 & 53.01 & 2 & 7 \\
\hline 65 & 53.52 & 2 & 7 \\
\hline 66 & 54.09 & 1 & 5 \\
\hline 67 & 51.32 & 2 & 7 \\
\hline 68 & 53.52 & 2 & 7 \\
\hline 69 & 53.61 & 1 & 6 \\
\hline 70 & 53.52 & 2 & 7 \\
\hline 71 & 51.84 & 3 & 8 \\
\hline 72 & 51.92 & 2 & 7 \\
\hline 73 & 51.81 & 2 & 6 \\
\hline 74 & 52 & 2 & 5 \\
\hline 75 & 51.32 & 2 & 7 \\
\hline 76 & 51.32 & 2 & 7 \\
\hline 77 & 50.75 & 3 & 9 \\
\hline 78 & 55.12 & 2 & 7 \\
\hline 79 & 51.92 & 2 & 7 \\
\hline 80 & 49.73 & 2 & 7 \\
\hline
\end{tabular}

${ }^{\mathrm{a}} \mathrm{Sv}$ sum of atomic van der Waals volumes (scaled on Carbon atom) Constitutional indices, ${ }^{\mathrm{b}} \mathrm{nDB}$ number of double bonds Constitutional indices, ${ }^{\mathrm{c}} \mathrm{nO}$ number of Oxygen atoms Constitutional indices.

Development of Quantitative structure-activity relationship model was carried out by sequential MLR method using VALSTAT program [17]. The validation of Quantitative structure-activity relationship models "Leave-one-out (LOO)" method was utilized. The greatest model was chosen on the basis of various statistical parameters such as correlation coefficient $(R)$, square of correlation coefficient $\left(R^{2}\right)$, sequential Fischer test $(F)$. The correlative and predictive ability of the each model was estimated from the cross-validated squared correlation coefficient $\left(\mathrm{Q}^{2}\right)$, standard deviation of prediction $\left(\mathrm{S}_{\mathrm{PRESS}}\right)$, and standard deviation of error of prediction $\left(\mathrm{S}_{\mathrm{DEP}}\right)$. Bootstrapping square correlation coefficient $\left(\mathrm{R}_{\mathrm{bt}}^{2}\right)$ was calculated which authenticate the robustness and applicability of QSAR equation. The derived QSAR model was applied for the prediction of the activity values of the compounds in the test set and the exterior validation parameter, predictive $\mathrm{R}^{2}\left(\mathrm{R}_{\text {pred }}{ }^{2}\right.$ ) was calculated to assess the predictive capacity of the model. Various $\mathrm{r}_{\mathrm{m}}{ }^{2}$ metrics were also calculated to validate the model further on stringent condition $[18,19]$.

The $\mathrm{Z}$ score method was adopted for the finding of outliers. $\mathrm{Z}$ score can be explaining as an absolute difference between the value of the model and the activity field, divided by the square root of the mean square error of the data set. Any compound having a Z score higher than 2.5, during generation of a particular QSAR model, is measured as an outlier.

\section{RESULT AND DISCUSSION}

In current study authors tried to develop a Quantitative structure-activity relationship model to clarify the correlation between physicochemical parameters and renin inhibitors. A data set of 80 piperazine and keto piperazine based renin inhibitors was used in the present study.

Several equations were raised when data set subjected to sequential multiple linear regression analysis. Out of these the most statistically significant equation was regarded as the best model.

$\mathbf{B A}=[-3.16542( \pm 2.41293)]+\mathrm{Sv}[0.217772( \pm 0.0590015)]+\mathrm{nDB}[1.19936( \pm 0.437316)]+\mathrm{nO}[-0.322083( \pm$ $0.322204)]$

The statistical parameters for this model are presented in Table 3 . The model presented above was considered as the best model due to its overall predictivity. The inter correlation between few descriptors was found to be high (Table 4), which could be owing to synergistically interacting descriptors. Furthermore, the multicollinearity arising from utilization of correlated descriptors is not a serious problem as assumed often. There are several examples of cases where pairs of highly correlated, descriptors generated the highly significant regression equations [20 - 24]. 
Table 3. Quantitative structure-activity relationship statistics of important equation\#.

\begin{tabular}{|c|c|}
\hline Parameters & Statistical values \\
\hline $\mathrm{N}$ Train & 56 \\
\hline $\mathrm{N}$ test & 24 \\
\hline $\mathrm{NV}$ & 3 \\
\hline $\mathrm{R}$ & 0.920 \\
\hline $\mathrm{R}^{2}$ & 0.846 \\
\hline Variance & 0.335 \\
\hline $\mathrm{Std}$ & 0.578 \\
\hline $\mathrm{F}$ & 95.465 \\
\hline $\mathrm{R}_{\mathrm{bt}}$ & 0.852 \\
\hline $\mathrm{Chance}$ & $<0.001$ \\
\hline $\mathrm{Q}$ & 0.818 \\
\hline $\mathrm{SPRESS}$ & 0.629 \\
\hline SDEP & 0.606 \\
\hline $\mathrm{R}^{2}$ pred & 0.821 \\
\hline $\mathrm{r}_{\mathrm{m}}{ }^{2}($ Loo $)$ & 0.799 \\
\hline $\mathrm{r}_{\mathrm{m}}{ }^{2}$ (Predicated) & 0.675 \\
\hline $\mathrm{r}_{\mathrm{m}}{ }^{2}$ (Overall) & 0.782 \\
\hline
\end{tabular}

$\# \mathrm{~N}$ Train= number of training set, $\mathrm{N}$ Test $=$ number of test set, $\mathrm{NV}=$ number of variables, $\mathrm{R}=$ coefficient of correlation, $\mathrm{R}^{2}=$ squared correlation coefficient, $\mathrm{Std}=$ standard deviation of estimation, $\mathrm{F}=$ Fischer's value, $\mathrm{R}_{\mathrm{bt}}^{2}=$ bootstrapping square correlation coefficient, $\mathrm{Q}^{2}=$ cross-validated squared correlation coefficient, SPRESS = predictive residual sum of square, $S_{D E P}=$ standard error of prediction. $R^{2}=$ predicted coefficient of correlation

Table 4. Correlation among structural descriptors and with the activity.

\begin{tabular}{|c|c|c|c|c|}
\hline Parameters & $\operatorname{logIC}_{50}(\mathbf{M})$ & Sv & nDB & nO \\
\hline $\operatorname{logIC}(\mathrm{M})$ & 1 & & & \\
\hline $\mathrm{Sv}$ & 0.838511 & 1 & & \\
\hline $\mathrm{nDB}$ & 0.786293 & 0.594754 & 1 & \\
\hline $\mathrm{nO}$ & 0.751425 & 0.673352 & 0.911668 & 1 \\
\hline
\end{tabular}

The model displays a good $(\mathrm{R})$ of 0.920 between the descriptors $\mathrm{Sv}, \mathrm{nDB}, \mathrm{nO}$ for rennin binding affinity. The squared $\left(\mathrm{R}^{2}\right)$ of 0.846 indicates $84.6 \%$ of the variance in the biological activity. This model also illustrates significance level more than $95 \%$ with $\mathrm{F}$ value $=95.465$, a low standard deviation of estimation 0.578 , establish the accuracy of the model. The stability of the model evaluated by leave-one-out method is literally superior $\left(\mathrm{Q}^{2}>0.6\right)$ suggesting the effectiveness of model for consequential predictions. The robustness of model was shown by magnitude of the $\mathrm{R}_{b t}^{2}$ (0.852), which was close to conventional $\mathrm{R}^{2} 0.846$ ). Additional help in this regard was found from the small values of the cross-validation parameters $S_{\text {PRESS }}$ and $S_{\text {DEP. }}$. The predicted $\mathrm{R}^{2}$ value of the test sets was 0.821 , representing brilliant predictive capacity of the model. The calculated, predicted and observed values of biological activity are exposed in Table 5 and Table 6 respectively. The association between predicted activity (LOO) and observed of the training and test set is shown in Fig. (1).

Table 5. Comparative biological activity $\left[\operatorname{logIC} \mathrm{C}_{50}(\mathrm{M})\right]$ of the training set.

\begin{tabular}{|c|c|c|c|}
\hline Compound no. & Observed activity & Calculated activity & Predicted activity \\
\hline 1 & 7.180 & 6.465 & 6.446 \\
\hline 2 & 6.742 & 6.117 & 5.095 \\
\hline 3 & 6.648 & 5.836 & 5.821 \\
\hline 4 & 6.609 & 5.860 & 5.941 \\
\hline 6 & 6.488 & 5.964 & 6.150 \\
\hline 7 & 6.472 & 6.160 & 5.928 \\
\hline 9 & 6.213 & 5.949 & 5.941 \\
\hline 10 & 6.056 & 5.949 & \\
\hline
\end{tabular}




\begin{tabular}{|c|c|c|c|}
\hline Compound no. & Observed activity & Calculated activity & Predicted activity \\
\hline 11 & 5.803 & 5.860 & 5.863 \\
\hline 13 & 7.167 & 6.232 & 6.203 \\
\hline 14 & 6.652 & 5.964 & 5.934 \\
\hline 16 & 6.971 & 6.384 & 6.369 \\
\hline 17 & 6.879 & 6.256 & 6.237 \\
\hline 19 & 5.399 & 5.091 & 5.053 \\
\hline 20 & 4.963 & 4.954 & 4.954 \\
\hline 22 & 5.848 & 5.470 & 5.421 \\
\hline 25 & 6.907 & 6.594 & 6.585 \\
\hline 27 & 7.432 & 7.428 & 7.427 \\
\hline 28 & 5.154 & 5.812 & 5.848 \\
\hline 29 & 5.253 & 5.836 & 5.867 \\
\hline 32 & 5.462 & 6.334 & 6.359 \\
\hline 33 & 7.194 & 6.222 & 6.054 \\
\hline 34 & 4.360 & 5.106 & 5.139 \\
\hline 36 & 5.298 & 5.106 & 5.098 \\
\hline 37 & 4.799 & 5.106 & 5.120 \\
\hline 38 & 5.363 & 5.259 & 5.254 \\
\hline 40 & 4.807 & 5.091 & 5.127 \\
\hline 41 & 5.416 & 5.836 & 5.858 \\
\hline 42 & 4.516 & 5.091 & 5.163 \\
\hline 43 & 5.762 & 6.465 & 6.484 \\
\hline 44 & 5.388 & 5.836 & 5.859 \\
\hline 45 & 4.377 & 4.978 & 5.006 \\
\hline 49 & 4.470 & 5.202 & 5.301 \\
\hline 50 & 6.224 & 5.494 & 5.398 \\
\hline 52 & 4.625 & 5.607 & 5.660 \\
\hline 53 & 5.770 & 5.631 & 5.624 \\
\hline 54 & 5.991 & 6.520 & 6.604 \\
\hline 55 & 5.594 & 5.607 & 5.608 \\
\hline 56 & 4.581 & 5.607 & 5.662 \\
\hline 60 & 6.270 & 6.602 & 6.618 \\
\hline 61 & 5.866 & 5.607 & 5.594 \\
\hline 62 & 9.770 & 9.381 & 9.329 \\
\hline 65 & 9.444 & 8.634 & 8.571 \\
\hline 67 & 8.790 & 8.155 & 8.121 \\
\hline 68 & 8.770 & 8.634 & 8.623 \\
\hline 69 & 8.499 & 7.776 & 7.685 \\
\hline 70 & 8.408 & 8.634 & 8.651 \\
\hline 71 & 8.398 & 9.145 & 9.246 \\
\hline 73 & 8.332 & 8.584 & 8.613 \\
\hline 74 & 8.301 & 8.947 & 9.247 \\
\hline 75 & 8.222 & 8.155 & 8.151 \\
\hline 76 & 8.222 & 8.155 & 8.151 \\
\hline 77 & 8.166 & 8.586 & 8.703 \\
\hline 78 & 8.046 & 8.982 & 9.090 \\
\hline 79 & 8.018 & 8.285 & 8.301 \\
\hline 80 & 8.000 & 7.809 & 7.798 \\
\hline
\end{tabular}

Table 6. Comparative biological activity $\left[\log I C_{50}(M)\right]$ of the test set.

\begin{tabular}{|c|c|c|}
\hline Compound no. & Observed activity & Predicted activity \\
\hline 5 & 6.530 & 5.964 \\
\hline 8 & 6.343 & 5.836 \\
\hline
\end{tabular}




\begin{tabular}{|c|c|c|}
\hline Compound no. & Observed activity & Predicted activity \\
\hline 12 & 5.413 & 5.949 \\
\hline 15 & 6.429 & 6.160 \\
\hline 18 & 9.377 & 8.634 \\
\hline 21 & 7.268 & 6.465 \\
\hline 23 & 6.818 & 6.489 \\
\hline 24 & 6.085 & 6.334 \\
\hline 26 & 6.054 & 6.513 \\
\hline 30 & 5.416 & 4.899 \\
\hline 31 & 6.277 & 6.334 \\
\hline 35 & 4.939 & 5.259 \\
\hline 39 & 4.220 & 5.302 \\
\hline 46 & 6.000 & 6.202 \\
\hline 47 & 4.117 & 5.202 \\
\hline 48 & 4.679 & 5.333 \\
\hline 51 & 5.703 & 5.956 \\
\hline 57 & 6.777 & 6.813 \\
\hline 58 & 6.648 & 6.602 \\
\hline 59 & 5.820 & 7.031 \\
\hline 63 & 9.745 & 8.523 \\
\hline 64 & 9.456 & 8.523 \\
\hline 66 & 9.276 & 8.203 \\
\hline 72 & 8.388 & 8.285 \\
\hline
\end{tabular}

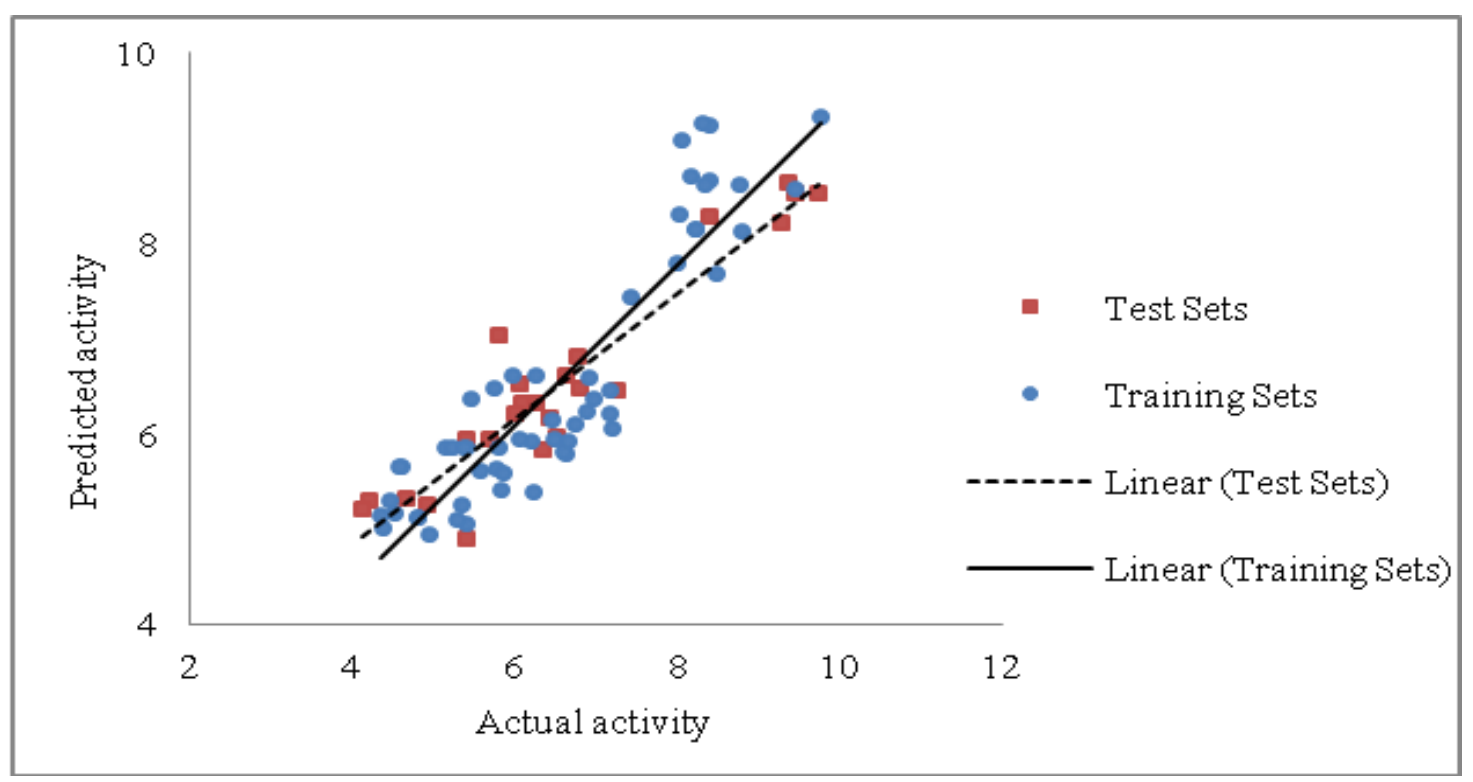

Fig. (1). Chart of actual activity $v s$. predicted activity for the training set and test set.

The QSAR study revealed that Sv and $\mathrm{nDB}$ descriptors have positive involvement to the renin inhibitory activity while $\mathrm{nO}$ has negative contribution to the renin inhibitory activity. All the three descriptors are 0D-constitutional indices, which are independent from molecular connectivity and conformations [25]. The predominant positive effect of Sv can be seen by observing the most potent compounds (compound no. 18 and 62-65). All these compounds have benzo-oxazine moiety with ester or ether side chain or tetrahydro quinoline with amide side chain, which provide bulkiness to molecule as shown in Fig. (2). 
<smiles>CCOC(=O)CN1C(=O)COc2ccc(SC[C@H]3CNCC(=O)N3c3ccc(OCCCOCc4ccccc4OC)cc3)cc21</smiles>

62

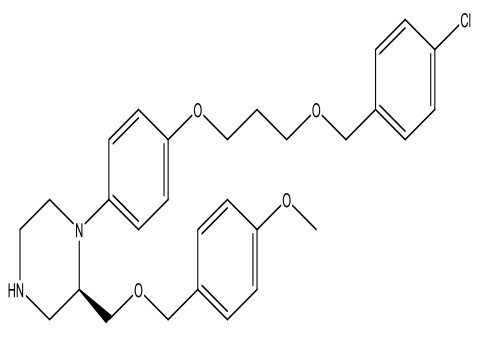

34

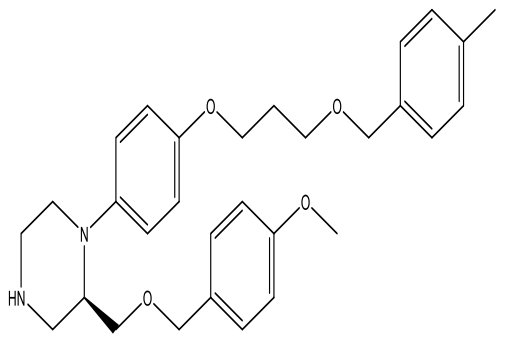

39

Fig. (2). Structures of most potent compound (62) and least potent compound (34, 39, 45, 47, and 49).

There are hydrophobic and hydrophilic amino acids both in the renin molecule. The hydrophilic amino acids are found outside the molecule, while the hydrophobic amino acids tends to be more on the inner side. The hydrophobic amino acids form the active site, a large hydrophobic pocket which can cover a molecule with minimum seven residues. Hydrogen bonding is the prime link between a renin and the ligand [26, 27]. For efficient and specific binding, the receptor cavity, in most cases, must be tightly filled with the interacting ligand. The increased van der Waals volumes could be helping the drug to place the drug residue in close proximate with amino acids in the hydrophobic pocket. The least potent compounds (compound no. 34, 39, 47, 49) are free from bulkiness provided by benzo-oxazine moiety or quinoline rings in Fig. (2). Positive contribution of $\mathrm{nDB}$ indicates that introduction of extra aromatic/heterocyclic ring or doubly bonded hetero atom increases the binding affinity. It is clearly seen that all the most potent compounds have extra one or two carbonyl group either as an ester or an amide. The little negative effect of descriptor nO is due to replacement of ether linkage between piperazine and benzoxazine ring, with thioether in most potent compounds (compound no. 62 and 63).

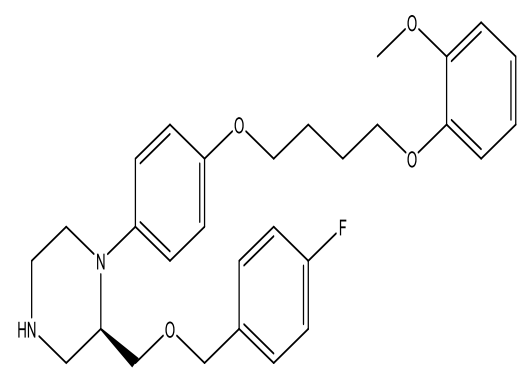

45

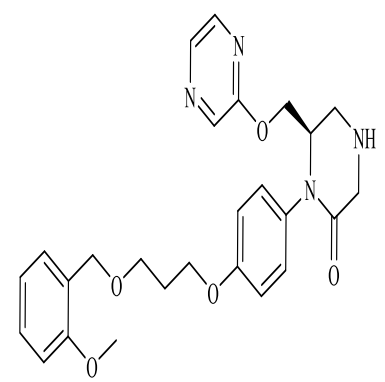

47

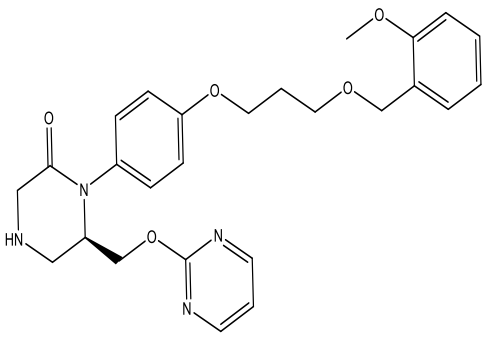

49

\section{CONCLUSION}

A developed QSAR model for piperazines and keto piperazines was found to be robust and accurate. This model can be used for designing the novel renin enzyme inhibitors in future.

\section{CONFLICT OF INTEREST}

The authors confirm that this article content has no conflict of interest.

\section{ACKNOWLEDGEMENTS}

Declared none.

\section{REFERENCES}

[1] Berl T. Review: renal protection by inhibition of the renin-angiotensin-aldosterone system. J Renin Angiotensin Aldosterone Syst 2009; 10(1): 1-8.

[http://dx.doi.org/10.1177/1470320309102747] [PMID: 19286752]

[2] Lindsay KB, Skrydstrup T. Formal total synthesis of the potent renin inhibitor aliskiren: application of a SmI2-promoted acyl-like radical coupling. J Org Chem 2006; 71(13): 4766-77. 
[http://dx.doi.org/10.1021/jo060296c] [PMID: 16776501]

[3] Hollenberg NK. Renin report: spotlight on Renin: therapeutic opportunities for Renin inhibitors. J Renin Angiotensin Aldosterone Syst 2005; 6(2): 107-9.

[http://dx.doi.org/10.3317/jraas.2005.008] [PMID: 16470491]

[4] Brown MJ. Direct Renin inhibition - a new way of targeting the Renin system. J Renin Angiotensin Aldosterone Syst 2006; 7(Suppl. 2): S7S11. [http://dx.doi.org/10.3317/jraas.2006.035]

[5] Wood JM, Maibaum J, Rahuel J, et al. Structure-based design of aliskiren, a novel orally effective renin inhibitor. Biochem Biophys Res Commun 2003; 308(4): 698-705. [http://dx.doi.org/10.1016/S0006-291X(03)01451-7] [PMID: 12927775]

[6] Azizi M, Webb R, Nussberger J, Hollenberg NK. Renin inhibition with aliskiren: where are we now, and where are we going? J Hypertens $2006 ; 24(2): 243-56$.

[http://dx.doi.org/10.1097/01.hjh.0000202812.72341.99] [PMID: 16508564]

[7] Cohen NC. Structure-based drug design and the discovery of aliskiren (Tekturna): perseverance and creativity to overcome a R\&D pipeline challenge. Chem Biol Drug Des 2007; 70(6): 557-65. [http://dx.doi.org/10.1111/j.1747-0285.2007.00599.x] [PMID: 17999663]

[8] Daugherty KK. Aliskiren. Am J Health Syst Pharm 2008; 65(14): 1323-32. [http://dx.doi.org/10.2146/ajhp070529] [PMID: 18593678]

[9] Jensen C, Herold P, Brunner HR. Aliskiren: the first renin inhibitor for clinical treatment. Nat Rev Drug Discov 2008; 7(5): 399-410. [http://dx.doi.org/10.1038/nrd2550] [PMID: 18340340]

[10] Holsworth DD, Cai C, Cheng XM, et al. Ketopiperazine-based renin inhibitors: optimization of the "C" ring. Bioorg Med Chem Lett 2006; 16(9): 2500-4. [http://dx.doi.org/10.1016/j.bmcl.2006.01.084] [PMID: 16480874]

[11] Holsworth DD, Powell NA, Downing DM, et al. Discovery of novel non-peptidic ketopiperazine-based renin inhibitors. Bioorg Med Chem 2005; 13(7): 2657-64. [http://dx.doi.org/10.1016/j.bmc.2005.01.048] [PMID: 15755665]

[12] Bezençon O, Bur D, Weller T, et al. Design and preparation of potent, nonpeptidic, bioavailable renin inhibitors. J Med Chem 2009; 52(12): 3689-702.

[http://dx.doi.org/10.1021/jm900022f] [PMID: 19358611]

[13] Leon AJ. Piperazine derivative Renin inhibitors. United States patent US 20,040,214,832., 2004.

[14] Rosenberg SH, Spina KP, Condon SL, et al. Studies directed toward the design of orally active renin inhibitors. 2. Development of the efficacious, bioavailable renin inhibitor (2S)-2-benzyl-3- [[(1-methylpiperazin-4-yl)sulfonyl]propionyl]-3-thiazol-4-yl-L-alanine amide of (2S,3R,4S)-2-amino-1-cyclohexyl-3,4-dihydroxy-6-methylheptane (A-72517). J Med Chem 1993; 36(4): $460-7$. [http://dx.doi.org/10.1021/jm00056a006] [PMID: 8474102]

[15] Version 80, Cambridge Soft Corporation. Software Publishers Association: Washington, D.C. 20036. 1730.1730 M Street, NW, Suite 700

[16] DRAGON for Windows In: ver55, Talete srl. Milano, Italy 2007.

[17] Gupta AK, Arockia BM, Kaskhedikar SG. VALSTAT, Validation program for quantitative structure activity relationship studies. Indian J Pharm Sci 2004; 66(4): 396-402.

[18] Ojha PK, Mitra I, Das RN, Roy K. Further exploring $\mathrm{r}_{\mathrm{m}}{ }^{2}$ metrics for validation of QSPR models. Chemometr Intell Lab 2011; 107(1): 194-205.

[http://dx.doi.org/10.1016/j.chemolab.2011.03.011]

[19] Roy k, Chakraborty P, Mitra I, Ojha PK, Kar S, Das RN. Some case studies on application of "rm2" metrics for judging quality of quantitative structure-activity relationship predictions: Emphasis on scaling of response data. J Comput Chem 2013; 34(12): 1071-82. [http://dx.doi.org/10.1002/jcc.23231] [PMID: 23299630]

[20] Patel JR, Prajapati LM. Predictive QSAR modeling on tetrahydropyrimidine-2-one derivatives as HIV-1 protease enzyme inhibitors. Med Chem Res 2013; 22(6): 2795-801.

[http://dx.doi.org/10.1007/s00044-012-0275-8]

[21] Peterangelo SC, Seybold PG. Synergistic Interactions among QSAR Descriptors. Int J Quantum Chem 2004; $96(1)$ : 1-9. [http://dx.doi.org/10.1002/qua.10591]

[22] Prajapati LM, Patel MJ, Parmar VK, Patel JR. Development of QSAR model for prediction of fold selectivity of phenyl benzoxazole as estrogen receptor inhibitors. Med Chem Res 2012; 21(11): 3681-6.

[http://dx.doi.org/10.1007/s00044-011-9920-x]

[23] Todeschini R, Consonni V. Handbook of Molecular Descriptors: Methods and Principles in Medicinal Chemistry. Weinheim, Germany: Wiley-VCH 2000. [http://dx.doi.org/10.1002/9783527613106]

[24] Prajapati LM, Parmar VK, Patel MJ, Patel JR. Development of QSAR model for indoyl aryl sulfone derivatives as reverse transcriptase 
inhibitors. Der Pharma Chemica 2011; 3(6): 53-61.

[25] Prajapati LM, Patel JR, Parmar VK. Descriptors requirement for QSAR analysis of pyrazolo-triazolo-pyrimidine derivative as human A3 receptor antagonists: design of novel furan derivatives and validation by docking. Med Chem Res 2014; 23(5): $2554-63$. [http://dx.doi.org/10.1007/s00044-013-0849-0]

[26] Matter H, Scheiper B, Steinhagen H, Böcskei Z, Fleury V, McCort G. Structure-based design and optimization of potent renin inhibitors on 5or 7-azaindole-scaffolds. Bioorg Med Chem Lett 2011; 21(18): 5487-92. [http://dx.doi.org/10.1016/j.bmcl.2011.06.112] [PMID: 21840215]

[27] Yuan J, Simpson RD, Zhao W, et al. Biphenyl/diphenyl ether renin inhibitors: filling the S1 pocket of renin via the S3 pocket. Bioorg Med Chem Lett 2011; 21(16): 4836-43. [http://dx.doi.org/10.1016/j.bmcl.2011.06.043] [PMID: 21741239]

Received: July 22, 2015 Revised: February 9, 2016 Accepted: February 17, 2016

(C) Patel and Prajapati; Licensee Bentham Open.

This is an open access article licensed under the terms of the Creative Commons Attribution-Non-Commercial 4.0 International Public License (CC BY-NC 4.0) (https://creativecommons.org/licenses/by-nc/4.0/legalcode), which permits unrestricted, non-commercial use, distribution and reproduction in any medium, provided the work is properly cited 